\title{
Review
}

\section{Vitamin $E$ in immunity and reproductive performance in pigs}

\author{
Araceli PINELLI-SAAVEDRA* \\ Department of Animal Nutrition, Centro de Investigación en Alimentación y Desarrollo, \\ A.C., Carretera a la Victoria km 0.6, Apdo. Postal No. 1735, 83000 Hermosillo, Sonora, Mexico
}

(Received 28 January 2003; accepted 28 August 2003)

\begin{abstract}
This review is focused on studies of vitamin E in immunity and reproductive performance in pigs. There are reports that vitamin $\mathrm{E}$ can have a positive effect on some parameters of the immune system in pigs. The optimal level of vitamin $\mathrm{E}$ needed to improve the immune system has not been determined because of several factors such as the composition of the diet, feed consumption, the rate of animal growth and living conditions or stress. Moreover, the way of action of vitamin $\mathrm{E}$ in enhancing immunity is still unclear but according to reports it may have antioxidant properties as well as an immunomodulator effect. In several studies, an increase in litter size and a reduction of preweaning piglet mortality have resulted from increasing dietary vitamin $\mathrm{E}$ intake during gestation or by intramuscular injection of vitamin $\mathrm{E}$ and/or selenium. However, according to reports, the positive effect of vitamin $\mathrm{E}$ on reproductive performance remains unclear due to the low number of animals used in most experiments.
\end{abstract}

\section{vitamin E / pig / immunity / reproductive performance / placental transfer}

\section{INTRODUCTION}

Vitamin $\mathrm{E}$ is a lipid soluble vitamin and is the generic name for all tocol and tocotrienol derivates that exhibit different degrees of biological activity [1], with $\alpha$-tocopherol being the most biologically active, accounting for approximately $90-100 \%$ of the vitamin $\mathrm{E}$ found in tissue [2]. $\alpha$-Tocopherol is an indispensable component of biological membranes with membrane-stabilising properties [3]. Vitamin E is absorbed through fat digestion facilitated by the emulsifi- cation process of bile and pancreatic lipase, whether vitamin $\mathrm{E}$ is present as a free alcohol or as the esterified form in the small intestine [4-6].

Tocopherols are transported in the blood by plasma lipoproteins. Although tocopherols are found in all lipoproteins, most are transported in the LDL lipoprotein fraction $[7,8]$. The intracellular transport of vitamin $\mathrm{E}$ in the liver appears to involve specific tocopherol-binding proteins (TBP). TBP have been found to affect the transfer of vitamin $\mathrm{E}$ from the cytoplasm to the

\footnotetext{
*Corresponding author: pinelli@cascabel.ciad.mx
} 
endoplasmic reticulum and mitochondria. In addition, intracellular vitamin E-binding lipoproteins have been identified in several tissues (liver, heart, brain, intestinal mucosa), and appear to participate in the intracellular transport of tocopherols $[1,8]$.

Vitamin $\mathrm{E}$ is an important constituent of all the membranes found in cells including the plasma, mitochondrial and nuclear membranes [7, 9, 10]. Vitamin $\mathrm{E}$ is the major chain-breaking antioxidant in the body tissues and is considered the first line of defence against lipid peroxidation, protecting cell membranes at an early stage of free radical attack through its free radical scavenging activity. If vitamin $\mathrm{E}$ is absent from the diet one would predict damage to cell membranes including immune and reproductive cells. This review was focused on studies of vitamin $\mathrm{E}$ in immunity and reproductive performance in pigs because there are several reports which suggest that vitamin $\mathrm{E}$ has a positive effect on some parameters of cellular and humoral response as well as on reproductive performance (litter size, mortality, piglet weight at birth and/or at weaning).

\section{INDICATORS OF VITAMIN E STATUS}

Vitamin E ( $\alpha$-tocopherol) status is commonly assessed by measuring plasma (or serum) concentration. In most species including pigs it has been shown that there is a strong correlation between plasma and liver levels of $\alpha$-tocopherol, and between dietary $\alpha$-tocopherol intake and plasma levels. In pigs, the plasma, tissues, colostrum and milk concentrations of vitamin $\mathrm{E}$ are highly responsive and directly correlated with changes in the dietary vitamin $\mathrm{E}$ intake. The data presented in Table I show that by increasing dietary $\alpha$-tocopherol levels, vitamin $\mathrm{E}$ concentration in sow plasma, colostrum and milk, piglet serum and in different tissues is increased. Thus, these indices are frequently used to assess vitamin $\mathrm{E}$ status and availability [11-14]. Vitamin E is transported into the bloodstream by lowdensity lipoproteins and although the amount in transport varies with the time of recent food absorption, it is a reasonably good indicator of status. Therefore, it is important to take into account the timing of blood sampling after feeding when blood is used to determine the vitamin $\mathrm{E}$ status.

\section{TOXICITY}

Vitamin E toxicity has not been demonstrated in swine. Levels as high as $1.2 \mathrm{~g} \cdot \mathrm{day}^{-1}$ in diets have been fed to growing-finishing pigs without showing toxic effects [15]. No signs of toxic effects have been reported in studies on rats, chicks and humans using vitamin $\mathrm{E}$ in the range of $1000-2000 \mathrm{mg} \cdot \mathrm{kg}^{-1}$ of diet $[1,5,16]$.

\section{BIOLOGICAL EFFECTS OF VITAMIN E}

\subsection{Vitamin $\mathrm{E}$ as an antioxidant}

One of the most important functions of vitamin $\mathrm{E}$ ( $\alpha$-tocopherol) is as an antioxidant in biological membranes where it protects polyunsaturated fatty acids and other components of cellular membranes from oxidation by free radicals $[1,17]$.

If lipid hydroperoxides are formed in the absence of an adequate supply of tocopherols, direct cellular damage can result [18]. Vitamin E reacts as a chain-breaking antioxidant, thereby neutralising free radicals and preventing the oxidation of lipids within membranes. The consequences of lipid peroxidation include damage to membranes, inhibition of enzyme activity and accumulation of reaction products [6]. There is a clear relationship between the biological activity of the tocopherols and their antioxidant activity [1].

The antioxidant property of vitamin $\mathrm{E}$ ensures the stability of the membranes of blood components such as erythrocytes, 
Vitamin E on immunity and reproduction

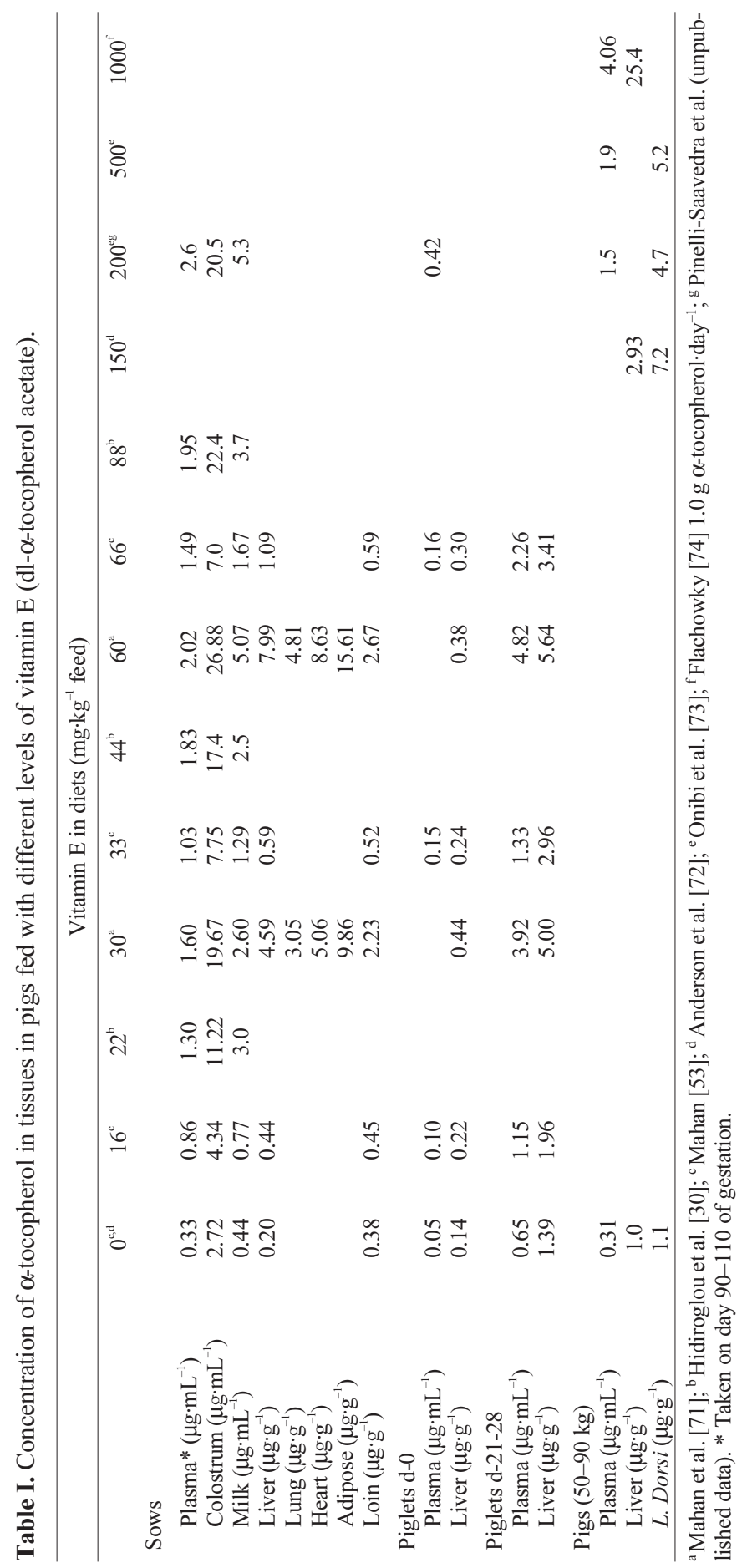


leukocytes and platelets and provides protection from oxidative damage by scavenging excess free radicals produced by oxidative stress. Erythrocytes have membranes which are rich in polyunsaturated lipids, and also contain haem proteins (cytochromes and haemoglobin) and transition metals $\left(\mathrm{Cu}^{2+}, \mathrm{Fe}^{2+}\right)$ which act as prooxidants. The latter makes the membrane lipids more susceptible to peroxidation, under circumstances of high oxygen concentration. When antioxidant defences in the blood are deficient, the susceptibility of erythrocytes to oxidative stress is increased and free radicals may attack their membranes leading to their oxidative destruction $[1,17,19]$.

Normally, there is a fine balance between the amount of free radicals generated in the body and the supply of antioxidants to protect against them. Thus the excess production of free radicals, or the lack of antioxidant protection, can shift this balance in favour of oxidative stress. It is now well recognised that oxidative stress plays a major role in many degenerative pathologies [20]. Free radical formation is considered as a pathobiochemical mechanism which is involved in the initiation phase of various human diseases, including cardiovascular diseases, some forms of cancer, muscular degeneration and a variety of neurodegenerative diseases. There are little data available on the effects of free radical overproduction and lipid peroxidation on animal health. It is known that the animal body is under constant attack from free radicals formed as a natural consequence of the body's metabolic activity and as part of the immune system's strategy for destroying invading microorganisms. It is widely believed that the antioxidant defence mechanisms used in animals are similar to those described for humans [21].

\subsection{Vitamin $E$ and immunity}

\subsubsection{Immunoadjuvant}

DL- $\alpha$-tocopherol acetate is a viscous oil that can be emulsified with an aqueous antigen to form a water in oil, oil in water, or double emulsion. Such adjuvants can be delivered directly to the tissues. In vaccination, such adjuvants may boost the immune response to weakly immunogenic antigens, as is the case with many protein antigens [22].

When vitamin $\mathrm{E}$ is in the oil phase in such an adjuvant, it is in close contact with antigen-processing cells and accessory cells that are attracted to the sites of injections by chemotaxis (peripheral mononuclear cells, lymphocytes and macrophages). This contact with the high local concentration of vitamin E (e.g. approximately $116 \mathrm{mg} \alpha-$ tocopherol per dose used) $[23,24]$, at the site of action assures the most favourable immunoenhancing effect of the vitamin, far more effectively than is possible by its dietary administration [25].

It has been reported that the inclusion of vitamin $E$ in a vaccination mixture results in an increase in the antibody titer and increases protection from infection in vitamin $\mathrm{E}$ adjuvant-vaccinated rams when given a Brucella ovis vaccine [26]. Also vitamin E has been successfully tested as an adjuvant in chicks showing, a significant improvement in antibody titers to Newcastle disease virus and $E$. coli antigens in the groups receiving the injection $[23,24]$. No data are available for pigs.

\subsubsection{Supplementation with vitamin $E$ and the immune response}

It has been suggested that vitamin E supplementation of diets has a considerable potential as a method of conferring increased resistance in the sow and the neonatal pig to enteric diseases such as E. coli, which is one of the most common diseases in the neonate and contributes to pre-weaning mortality [27].

Previous studies have shown that vitamin E supplementation of sow diets improves the immune response of sows and piglets. Vitamin E supplementation of weaned 
pigs (4-5 weeks of age) with $220 \mathrm{mg} \cdot \mathrm{kg}^{-1}$ of diet caused a significant increase in the antibody titre to a challenge with sheep red blood cells in weaned piglets (initial liveweight $7.0 \mathrm{~kg}$ ). The data suggest an effect of vitamin $E$ on the responsiveness of the humoral immune system [28]. In contrast, in pigs reared from 6 to $26 \mathrm{~kg}$ liveweight and supplemented with $210 \mathrm{mg}$ of vit $\mathrm{E} \cdot \mathrm{kg}^{-1}$ of diet and nursed by sows fed the National Research Council (NRC) estimated nutrient requirement for vitamin $\mathrm{E}$ and selenium. Bonnette [29] found no change in the antibody titer to a challenge with red blood cells. The differences between the two studies may have been due to differences in the initial concentration of serum vitamin $E$ which in the case of Bonnette [29] was $20 \mu \mathrm{g} \cdot \mathrm{mL}^{-1}$ compared to $4 \mu \mathrm{g} \cdot \mathrm{mL}^{-1}$ in the study of Peplowsky [28]. Recently, newborn piglets were injected with $500 \mathrm{mg}$ and $1000 \mathrm{mg}$ of vitamin $\mathrm{E}$ and $10 \mathrm{mg}$ of keyhole limpet haemocyanin (KLH) at 7 and 14 days of age. The antibody titres to the $\mathrm{KLH}$ challenge in the vitamin $\mathrm{E}$ injected piglets were significantly $(P<0.05)$ higher than in the control piglets at day 21 (17 vs. 2) and day 28 (1216 vs. 261). These treatments increased the $\alpha$-tocopherol concentration in the plasma from 2.52 to $7.22 \mu \mathrm{g} \cdot \mathrm{mL}^{-1}$ [30].

The supplementation of the diet with vitamin $\mathrm{E}$ in order to enhance the response to vaccines has been poorly studied. In an earlier study, a positive effect to vitamin $\mathrm{E}$ supplementation $\left(100 \mathrm{mg} \cdot \mathrm{kg}^{-1}\right.$ feed $)$ of pigs given an intramuscular injection of an Escherichia coli bacterin was found. In this experiment, the group supplemented with vitamin E developed two-to-three fold higher anti- $E$ coli serum antibody titers than those of the controls [31].

Cell-mediated immune responses to vitamin E supplementation have also been reported in pigs. An increased phytohaemagglutinin (PHA)-response in lymphocytes in pigs (20-90 kg) supplemented with vitamin $E$ at a level of $40 \mathrm{mg} \cdot$ day $^{-1}$ and selenium at levels of 0.5 and $0.1 \mathrm{ppm}$ has been reported
[32]. Vitamin E supplementation enhanced the mitogen response at both levels of selenium tested. The results showed that the group supplemented with vitamin $\mathrm{E}$ and no selenium gave a significantly greater response to PHA compared with the group supplemented with selenium alone but gave a significantly lower response than the groups supplemented with both selenium and vitamin E [32]. In another study, it was found that a high level of vitamin $\mathrm{E}(136 \mathrm{mg}$ $\alpha$-tocopherol $\cdot \mathrm{kg}^{-1}$ diet) and $0.1 \mathrm{mg} \mathrm{Se} \cdot \mathrm{kg}^{-1}$ in the sow diet influenced vitamin $\mathrm{E}$ concentration in the serum of piglets during the first days of lactation. The results indicate that immunisation with ovalbumin shows an increased humoral response $(P<0.05)$ 1 week after immunisation in pigs ( 5 weeks of age) from sows fed a high level of vitamin E. The results also suggest that the humoral response of pigs after weaning is increased by a carryover effect during lactation from sow diets containing a high level of vitamin E [33]. Dietary restriction of vitamin $\mathrm{E}$ in sow diets has been reported to depress peripheral blood lymphocytes and polymorphonuclear cell (PMN) immune functions whereas selenium restriction depresses mainly the PMN function [34]. This implies that if gestating sows do not obtain adequate vitamin $\mathrm{E}$ and/or selenium, they and their piglets are more susceptible to disease processes in the peripartum period. Although selenium restriction primarily impairs neutrophil function, vitamin $\mathrm{E}$ restriction affects both neutrophils and lymphocytes. Another study showed that only high levels of supplementation with vitamin E (110 and $220 \mathrm{mg} \cdot \mathrm{kg}^{-1}$ diet) in sow diets show a significantly $(P<0.05)$ higher cellular immune response to PHA and concanavalin A (Con A) stimulation of lymphocytes in the piglet at 28 days of age but not in the dams [35].

Also the effect of vitamin E on the cellular and humoral response has been studied in other species such as humans, cows and calves, sheep, and mice [25, 36-43]. Moreover, the immunodulatory property of vitamin E has been reported. These reports 
show that vitamin $\mathrm{E}$ may promote $\mathrm{T}$ cell helper 1 (Th1) differentiation and reduces interleukin-4 (IL-4) secretion [44-49]. In pigs, no data are available.

The optimal level of vitamin E needed to improve the immune system is still not clear. Early studies indicate that dietary $\alpha$-tocopherol (vitamin E) requirements for maintenance of optimal immune responsiveness in animals may be higher than the levels recommended for normal growth and reproduction. Dietary supplementation with 2-10 times more than the currently recommended level of vitamin E significantly increases humoral and cell-mediated immune responses and phagocytic functions in laboratory and farm animals including pigs and increases their resistance to infectious disease [50]. More recently, however, it has been reported in sows, turkey, and chicken that high levels of vitamin $E$ have no effect on immune response $[35,51]$.

\section{VITAMIN E AND REPRODUCTIVE PERFORMANCE}

In several studies, increased litter size and reduced preweaning piglet mortality result from increasing sow dietary vitamin $\mathrm{E}$ intake during gestation $[52,53]$ or by intramuscular injections of vitamin $\mathrm{E}$ and selenium [54-56]. In Table II the data of reports show an increase in litter size and piglet weight at birth after vitamin E with selenium supplementation. In contrast, supplementation of vitamin $\mathrm{E}$ alone did not have an effect at birth but there was an increase on litter size at weaning.

Mahan [53] fed gilts with Se and dl- $\alpha-$ tocopherol acetate supplemented in feed over three parities. Litter size at birth was increased in the gilts supplemented with vitamin E compared with the control.

In the study of Chavez et al. [54], a basal diet containing a total of $0.1 \mathrm{ppm}$ Se and $15 \mathrm{mg}$ vitamin $\mathrm{E} \cdot \mathrm{kg}^{-1}$ feed was used as the control. The sows in this single parity study were distributed into three groups: the basal diet; basal diet plus intramuscular injections containing $3 \mathrm{mg}$ Se and $408 \mathrm{mg}$ dl- $\alpha$-tocopherol and the third group which received the same injection schedule and an additional injection when the litter was weaned or approximately one week prior to artificial insemination. The injected groups had significantly different reproductive performances (litter size at birth and at weaning, total litter weight at birth, and mortality) compared to the non-injected animals for litter size at birth, live at weaning and total litter at birth and as well as a lower piglet mortality at birth. There was no significant difference between the control and the injected animals in mortality at weaning. The authors suggest that supplementation via periodic injections of vitamin $\mathrm{E}$ and selenium may result in increased litter size both at birth and weaning, as well as an increase in litter weight at birth [54].

Migdal and Kackzmarczyk [56] showed that the body weight of the piglets at birth from sows injected with Se and $\alpha$-tocopherol on 7 and 21 days before farrowing was significantly higher $(P<0.05)$ compared with the control group. Piglets from sows injected on day 21 and from sows injected on days 21 and 7 had significantly higher average daily weight gain from 1 day to 21 days of age compared with the control group. The mortality of piglets up to the age of 21 days from sows injected on day 21 was significantly lower $(5.06 \%)$ compared to piglets from sows in the control group (8.24\%). There were no differences in the litter size between the treatments. The authors concluded that the injection of Se and vitamin $\mathrm{E}$ in gestation results in a higher survival rate and better growth, in spite of the fact that daily diets (control) met requirements for these components [56].

Mavromatis et al. [55], reported that sows receiving a basal diet plus $30 \mathrm{mg} \alpha$-tocopherol $\cdot \mathrm{kg}^{-1}$ feed of plus three intramuscular selenium injections of $30 \mathrm{mg}$ on days 30,60 and 90 of gestation had the highest number 
Vitamin E on immunity and reproduction

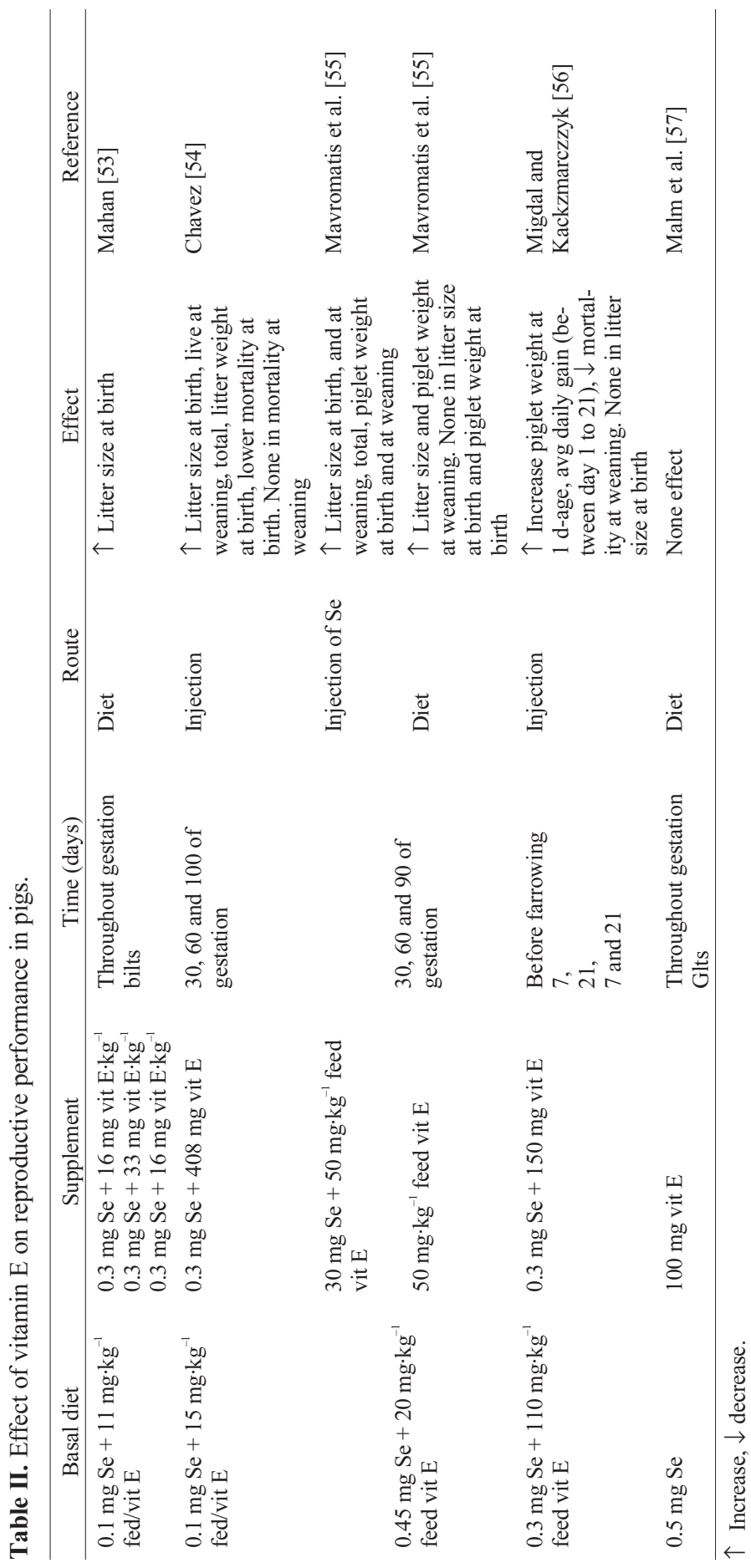


of weaned piglets and had a significantly higher $(P<0.05)$ litter size at birth and weaning compared to the other treatments and control. The difference in the average number of 1.06 weaned piglets/litter between the group of sows given the basal diet plus $30 \mathrm{mg} \alpha$-tocopherol $\cdot \mathrm{kg}^{-1}$ feed plus three intramuscular selenium injections of $30 \mathrm{mg}$ on days 30,60 and 90 of gestation and the other groups was significantly higher as well as piglet weight at birth and weaning. The mortality of piglets from sows supplemented with $\alpha$-tocopherol and injected $3 \mathrm{mg}$ selenium twenty-one days before farrowing was significantly lower $(5.06 \%)$ compared to piglets from sows in the control group (8.24\%). The authors concluded that Se supplementation was less effective than either $\alpha$-tocopherol supplementation alone or the combined supplementation of Se and $\alpha$-tocopherol $\left(50 \mathrm{mg} \cdot \mathrm{kg}^{-1}\right.$ feed) in the feed of pregnant and lactating sows [55].

In contrast, another study comparing control and semipurified diets containing $100 \mathrm{mg}$ $\alpha$-tocopherol $\cdot \mathrm{kg}^{-1}$ feed and $50 \mu \mathrm{g} \mathrm{Se} \cdot \mathrm{kg}^{-1}$ feed fed to pregnant gilts, showed no evidence of differences in reproductive performance. A trend existed for a larger litter size in the supplemented groups but a definitive conclusion could not be made because of the small number of sows used per treatment $(n=4)$ [57]. Other authors showed a similar a lack of response in litter size and weight to dietary vitamin E supplementation over one parity $[27,58]$.

It has been proposed that vitamin $\mathrm{E}$ in reproduction acts as an antioxidant with other enzyme systems like glutathione peroxidase, in order to protect the cell's reproductive system. Selenium is an important component of glutathione peroxidase. While vitamin E scavenges radicals within the membrane phase, glutathione peroxidase blocks the initiation of lipid peroxidation from within the soluble phase of the cell. Therefore vitamin $\mathrm{E}$ and selenium act in synchrony to prevent cell lipid peroxidation from oxygen radicals that are produced in reproductive organs like the corpus luteum during regression. The ovarian content of vitamin $\mathrm{E}$ changes dramatically during development and functional regression of the corpus luteum $[2,59]$. However, it has reported in female mice that vitamin $\mathrm{E}$ and vitamin C may have an effect on fertility [60].

\section{PLACENTAL TRANSFER OF VITAMIN E}

The status of vitamin $\mathrm{E}$ in the newborn piglet will depend on its dam. It is known that immediately after birth, the vitamin $\mathrm{E}$ content in the serum is increased after suckling colostrum and milk, but there is little evidence concerning the placental transfer of vitamin $E$ which could determine the vitamin E status of the newborn. It has been reported that the concentration of serum $\alpha$-tocopherol in unsuckled newborn piglets is several fold higher than that of their dams, strongly suggesting an efficient placental transfer of vitamin $\mathrm{E}$ even when the dams are not supplemented with the vitamin [57]. However, most reports have suggested that, prior to nursing, the $\alpha$-tocopherol concentration in the serum of neonatal piglets is low whether or not the dam is provided with adequate or supplemented dietary levels of vitamin E during gestation [30, 61-64]. The low plasma and tissue levels of $\alpha$-tocopherol in new-born pigs suggests a low rate of vitamin E transfer across the placenta which is not influenced by the dietary supplementation of the sow during pregnancy. Two studies have reported that $\alpha$-tocopherol concentrations of the neonate before nursing increase when the supplementary level of vitamin $\mathrm{E}$ in sow diets is increased but placental transfer of vitamin $\mathrm{E}$ is low [53, 65].

In other species like dairy calves and lambs, little transfer of vitamin $\mathrm{E}$ via the placenta has been reported [66-69]. In a study, supplemented ewes with dl-tocopheryl acetate $(0,15,30$ and $60 \mathrm{mg}$ each day) from 
day 28 prepartum to day 28 postpartum showed that supplementation with vitamin $E$ has no effect on serum $\alpha$-tocopherol content in neonatal lambs $\left(0.66 \mu \mathrm{g} \cdot \mathrm{mL}^{-1}\right)$ indicating an inefficient placental transfer. Serum $\alpha$-tocopherol content increases for the supplemented ewes after colostrum intake. In humans, poor placental transfer has been found [67]. In addition, supplementation with vitamin $E$ increases the concentration of $\alpha$-tocopherol in plasma and red blood cells in the mothers but the plasma vitamin $\mathrm{E}$ content is very low in the neonates after supplementation with vitamin E ( $1 \mathrm{~g} \alpha$-tocopherol-day $\left.{ }^{-1}\right)$ in 10 pregnant women for 3 days before delivery. It is concluded that the transfer of vitamin E through the placental barrier is very low [70]. The mechanism by which vitamin $\mathrm{E}$ is transferred via the placenta is still not clear.

\section{CONCLUSION}

In this review dietary supplementation or injection of vitamin $\mathrm{E}$ with selenium shows a positive effect on reproductive performance rather than vitamin $\mathrm{E}$ alone. To enhance the immune system it is necessary to increase (2-10 times) the dietary amount of vitamin $\mathrm{E}$ above the recommended level. However, to date it has been found that the variation of the effect of vitamin E on reproductive performance and on immunity depends on several factors such as the route of supplementation (injection and/or dietary), vitamin $\mathrm{E}$ status, the duration of supplementation, composition of the diet, feed consumption, rate of growth, animal pro duction and living conditions, stress, crowding and an environment making the recommendation of an optimal level of vitamin $E$ supplementation in pig diets difficult. Thus, it is important to continue research on vitamin $\mathrm{E}$ and its relation to immunity, specifically its effects as an immunomodulator and on reproductive performance in pigs, using combinations of selenium for different periods and/or using a large number of animals.

\section{REFERENCES}

[1] Combs GF. The Vitamins: Fundamental Aspects in Nutrition and Health. 2nd Ed. Academic Press, Ca, USA, 1998.

[2] Budowski PD, Sklan D. Vitamins E and A, in Vergroesen AJ, Crawford M (Eds), The Role of fats in Human Nutrition, Academic Press, London, 1989, p 364-406.

[3] Morrisey PA, Denis JB, Sheehy PJA, Monahan FJ. Vitamin E and meat quality. Proc Nutr Soc 1994, 53: 571-582.

[4] Green J. Tocopherols: biochemical systems. In: Sebrell WH, Harris RS (Eds), Vitamins: Chemistry, Physiology, Pathology, Method, Vol V, Academic Press New York, 1972, p 259-272.

[5] MacDowell LR. Vitamins in Animal Nutrition: Comparative Aspects to Human Nutrition. Academic Press, New York, 1989.

[6] Ullrey DE. Vitamin E for swine. J Anim Sci 1981, 53: 1039-1056.

[7] Machlin LJ, Filipski R, Willis AL, Kuhn DC, Brin M. Influence of vitamin E on platelet aggregation and thormobocytemia in rat. Proc Soc Exp Biol Med 1975, 149: 275-278.

[8] Traber MG, Cohn W, Muller DP. Absorption, Transport and Delivery of Tissue. In: Lester P, Fuch J. (Eds), Vitamin E in Health and Disease, Marcel Decker, New York, USA, 1993, p 44.

[9] Bjorneboe A, Bjorneboe GE, Drevon CA. Absorption, transport and distribution of vitamin $\mathrm{E}$. J Nutr 1990, 120: 233.

[10] Bonnetti E, Novello F. Distribution of ${ }^{3} \mathrm{H}-$ tocopherolin rat tissues and subcellular particles. Int J Vitam Nutr Res 1976, 46: 244-247.

[11] Batra TR, Hidiriglou M. Tissue vitamin E concentrations after single injection of alphatocopherol in pigs. Can J Anim Sci 1994, 74: 579-581.

[12] Burrin DG. Nutrient requirements and metabolism. In: Pond WG, Mersmann HJ. (Eds). Biology of Domestic Pig, Cornell University Press, Ithaca, 2001, p 309-389.

[13] Hidiroglou M, Farnworth AE, Butler G. Effect of vitamin $\mathrm{E}$ and fat supplementation on concentration of vitamin $\mathrm{E}$ in plasma and milk of sows and in plasma of piglets. Int J Vitam Nutr Res 1993, 63: 180-187.

[14] Mahan DC. Effects of dietary vitamin E on sow reproductive performance over five-parity period. J Anim Sci 1994, 72: 2870-2879.

[15] Flachowky G. Vitamin E-transfer from feed into pig tissues. J Appl Anim Res 2000, 17: 69-80.

[16] Machlin LJ. Vitamin E. In: Machlin LJ (Ed), Handbook of Vitamins, Marcel Dekker, Inc., New York, 1991, p 99-144. 
[17] Surai PF. Review of cellular antioxidant defences- vitamin, mineral, enzyme antioxidant defences. Meeting of Society of Feed Technologists. June 14th, UK, 2001.

[18] Duthie GG, Arthur JR. Vitamin E in relation to disease. Pig Vet J 1991, 27: 92-96.

[19] Urano S. The role of vitamin E in blood and cellular aging. In: Lester P, Fuch J (Eds), Vitamin E in Health and Disease. Marcel Decker, New York, USA, 1993, p 159-170.

[20] Flachowky G. Vitamin E-transfer from feed into pig tissues. J Appl Anim Res 2000, 17: 69-80.

[21] Roth JA. Immune system. In: Straw E, D'Allaire S, Mengeling WL, Taylor DJ (Eds), Disease of swine, Blackwell Science Ltd. Malden, 1999, p 21-39.

[22] Nervig RM, Gough PM, Kaeberle ML, Whetstone C. Advances in carriers and adjuvants for veterinary biologic. Iowa State University, 1986.

[23] Franchini A, Bertuzzi S, Tosarelli C, Manfreda G. Vitamin E in viral inactivated vaccines. Poult Sci 1995, 74: 666-671.

[24] Franchini A, Canti M, Manfreda G, Bertuzzi S. Vitamin $\mathrm{E}$ as adjuvant in emulsified vaccine for chicks. Poult Sci 1991, 70: 1709-1705.

[25] Meydani SN, Blumberg J, Yogeeswaran G, Maydani M. Antioxidants and the aging system. In: Bendish A, Phillips M, Tangerdy R (Eds), Antioxidants Nutrients and Immune Functions, Plenum Press, New York, 1989.

[26] Afzal MR, Tangerdym RP, Ellis RP, Kimberling $\mathrm{CV}$, Morris CJ. Protection of rams against epididymitis by a Brucella ovis vitamin E adjuvant vaccine. Vet Immunol Immunopathol 1984, 7: 293-304.

[27] Pharazyn A, Den Hartog LA, Aherne FX. Vitamin $\mathrm{E}$ and its role in the nutrition of the gilt and sow: a review. Livest Prod Sci 1990, 24: 1-13.

[28] Peplowski MA, Mahan DC, Murray FA, Moxon AL, Cantor AH, Ekstron KE. Effect of dietary and selenium in weanling swine antigenically challenged with sheep red blood cells. J Anim Sci 1981, 51: 344-351.

[29] Bonnette ED, Kornegay ET, Lindemann MD, Notter DR. Influence of two supplemental vitamin $\mathrm{E}$ levels and weaning age on performance, humoral antibody production and serum cortisol levels of pigs. J Anim Sci 1990, 68: 1346-1353.

[30] Hidiroglou M, Batra TR, Farnworth ER, Markham F. Effect of vitamin E supplementation on immune status and $\alpha$-tocopherol in plasma of piglets. Reprod Nutr Dev 1995, 35: 443-450.

[31] Ellis RP, Vorheis MW. Effect of supplemental dietary vitamin $\mathrm{E}$ on the serologic response to an Escherichia coli Bacterin. J Am Vet Med Assoc 1976, 168: 231-232.

[32] Larsen HJ, Tollersud S. Effect if dietary vitamin $\mathrm{E}$ and selenium on the phytohaemagglutinin response of pig lymphocytes. Res Vet Sci 1981, 31: 301-305.

[33] Babinszky L, Langhout DJ, Verstegen MWA, den Hartog P, Joling M, Nieuwland M. Effect of vitamin $\mathrm{E}$ and fat source in sows' diets on immune response of suckling and weaned piglets. J Anim Sci 1991, 69: 1833-1842.

[34] Waryastuti H, Stowe HD, Bull RW, Miller ER. Effects of vitamin E and selenium on immune responses of peripheral blood, colostrum and milk leukocytes of sows. J Anim Sci 1993, 71: 2464-2472.

[35] Nemec M, Butler G, Hidiroglou M, Farnworth ER, Nielsen K. Effect of supplementing gilts' diets with different levels of vitamin $\mathrm{E}$ and different fats on the humoral and cellular immunity of gilts and their progeny. J Anim Sci 1994, 72: 665-676.

[36] Batra TR, Singh K, Ho SK, Hidiroglou M. Concentration of plasma and milk vitamin $\mathrm{E}$ and plasma beta-carotene of mastitic and healthy cows. Int J Vitam Nutr Res 1992, 62: 233-237.

[37] Brennan LA, Morris GM, Wasson GR, Hanningan BM, Barnett YA. The effect of vitamin $\mathrm{C}$ or vitamin $\mathrm{E}$ supplementation on basal and $\mathrm{H}_{2} \mathrm{O}_{2}$-induced DNA damage in human lymphocytes. Br J Nutr 2000, 84: 195-202.

[38] Hogan JS, Smith KL, Weiss WP, Todhunter DA, Shockey WL. Relationships among vitamin E, selenium and bovine blood neutrophils. J Dairy Sci 1990, 73: 2372-2378.

[39] Politis I, Hidiroglou M, Batra TR, Gilmore JA, Gorewith RC, Scherf H. Effects of vitamin $\mathrm{E}$ on immune function of dairy cows. Am J Vet Res 1995, 56: 179-184.

[40] Pollock JM, Mcnair J, Kennedy S, Kennedy DG, Walsh DM. Effects of dietary vitamin E and selenium in vitro cellular immune responses in cattle. Res Vet Sci 1994, 56: 100-107.

[41] Reddy PG, Morrill JL, Minocha HC, Stevenson JS. Vitamin E is immunostimulatory in calves. J Dairy Sci 1987, 70: 993-999.

[42] Smith KL, Conrad HR, Amiet BA, Schoenberger PS, Todhunter DA. Effect of vitamin E and selenium dietary supplementation on mastitis in first lactation diary sows. J Dairy Sci 1985, 68 (Suppl): 190 (Abstract).

[43] Smith KL, Harrison JH, Hancock D, Todhunter DA, Conrad HR. Effect of vitamin E and selenium supplementation on incidence of clinical mastitis and duration of 
clinical symptoms. J Dairy Sci 1984, 67: 1293-1300.

[44] Han SN, Wu D, Ha WK, Beharka A, Smith DE, Bender BS, Meydani SN. Vitamin E supplementation increases $\mathrm{T}$ helper 1 cytokine production in old mice infected with influenza virus. Immunology 2000, 100: 487-493.

[45] Melmberg KJ, Lenkei R, Peterson M, Ohlum T, Ichihara F, Glimelius B, Frodin JE, Masucci G, Kiessling R. A short-term dietary supplementation of high doses of vitamin $\mathrm{E}$ increases $\mathrm{T}$ helper 1 cytokine production in patients with advanced colorectal cancer. Clin Cancer Res 2002, 6: 1772-1778.

[46] Morigushi S, Miwa M, Okamura H, Maekawa $\mathrm{K}$, Kishinom Y, Maeda L. Vitamin E is an important factor in $\mathrm{T}$ cell differentiation in thymus of F344 rats. J Nutr Sci Vitaminol 1993, 39: 451-463.

[47] Wang JY, Liang B, Watson RR. Vitamin E supplementation with interferon gamma administration retards immune dysfunction during murine retrovirus infection. J Leukocyte Biol 1995, 58: 698-703.

[48] Wang JY, Watson RR. Vitamin E supplementation at various levels alters cytokine production by thymocytes during retrovirus infection causing murine AIDS. Thymus 1994, 22: 153-165.

[49] Wang JY, Watson RR. Vitamin E supplementation at various levels alters cytokine production by thymocytes during retrovirus infection causing murine AIDS. Thymus 1994, 22: 153-165.

[50] Meydani SN, Tengerdy R. Vitamin E and immune response. In: Packer L, Fuch J (Eds), Vitamin E on Health and Disease, Marcel Decker, 1993, p 549-561.

[51] Friedman A, Bartov I, Sklan D. Humoral immune response impairment following excess vitamin E nutrition in the chick and turkey. Poult Sci 1998, 77: 956-962.

[52] Cline JH, Mahan DC, Moxon AL. Progeny effects of supplemental vitamin $\mathrm{E}$ in sow diets. J Anim Sci 1974, 39 (Abstract).

[53] Mahan DC. Assessment of the influence of dietary vitamin $\mathrm{E}$ on sows and offspring in three parities: reproductive performance, tissue tocopherol, and effects on progeny. J Anim Sci 1991, 69: 2904-2917.

[54] Chavez ER, Patton KL. Response to injectable selenium and vitamin $\mathrm{E}$ on reproductive performance of sows receiving a standard commercial diet. Can J Anim Sci 1986, 66: 1065-1074.

[55] Mavromatis J, Koptopoulos G, Kyriakis SC, Papasteriadis A, Saoulidis K. Effects of $\alpha$-tocopherol and selenium on pregnant sows and their piglets' immunity and performance. J Vet Med 1999, 46: 543-553.
[56] Migdal W, Kaczmarczyk J. Effect to injection of selenium and vitamin $\mathrm{E}$ on reproductive performance of sows and Se concentration in sow milk. World Rev Anim Prod 1993, 28: 68-71.

[57] Malm A, Pond WG, Walker EF Jr, Homan M, Aydin A, Kirtland D. Effect of polyunsaturated fatty acids and vitamin $E$ level of the sow gestation diet on reproductive performance and on level of alpha tocopherol in colostrum, milk and dam progeny blood serum. J Anim Sci 1976, 42: 393-399.

[58] Wilkinson JE, Bell MC, Bacon JA, Mansicupp FB. Effects of supplemental Se on swine. I. Gestation and lactation. J Anim Sci 1977, 44: 224-228.

[59] Chew BP. The influence of vitamins on reproduction in pigs. In: Garnsworithy PC, Cole DJA (Eds), Recent Advances in Animal Nutrition. Nottingham University Press, Nottingham UK, 1995, p 223-237.

[60] Tarin J, Ten J, Vendrell FJ, de Oliveira MN, Cano A. Effects of maternal ageing and dietary antioxidant supplementation on ovulation, fertilisation and embryo development in vitro in the mouse. Reprod Nutr Dev 1998, 38: 499-508.

[61] Babinszky L, Langhout DJ, Verstegen MWA, Hartog P, den Joling M, Nieuwland M. Effect of $\alpha$-tocopherol and dietary fat source on some blood and immunological variables in lactating sows. Anim Prod 1991, 52: 367-375.

[62] Farnworth ER, Butler G, Hidiroglou M. Foetal pig vitamin E status. Nutr Res 1995, 15: 1139-1147.

[63] Loudenslager MJ, Ku PK, Whitter PA, Ullrey DE, Whitehair CK, Stowe HD, Miller ER. Importance of diet of dam and colostrum to the biological antioxidant status and perenteral iron tolerance of the pig. J Anim Sci 1986, 63: 1905-1914.

[64] Young LG, Miller RB, Edmeades DE, Lun A, Smitz GC, King GL. Selenium and vitamin E supplementation of high moisture corn diets from swine production. J Anim Sci 1977, 45: 1051-1060.

[65] Piatkowski TL, Mahan DC, Cantor AH, Moxon AL, Cline JH, Grito AP Jr. Selenium and vitamin $\mathrm{E}$ in semi purified diets for gravid and nongravid gilts. J Anim Sci 1979, 48: 1357-1365.

[66] Hidiroglou M, MacAllister AJ, Williams CJ. Selenium distribution and radiotocopherol metabolism in the pregnant ewe and foetal lamb. Can J Physiol Pharm 1969, 47: 953-957.

[67] Njeru CA, MacDowell LR, Wilkinson NS, Linda SB, Williams S. Pre-and postpartum supplemental DL- $\alpha$-tocopheryl acetate effects on placental and mammary vitamin transfer in sheep. J Anim Sci 1994, 72: 1636-1640. 
[68] Nockels CF. Vitamin E requirements of beef cattle: influencing factors. BASF Technical Symposium, Bloomington, Minnesota, 1991, p 40-43.

[69] Van Suan RJ, Herdt TH, Stowe HD. Maternal and fetal selenium concentrations and their interrelationships in dairy cattle. J Nutr 1989, 119 : 1128-1133.

[70] Leger Cl, Dumontier C, Fouret G, Boulot P, Descomps B. A short term supplementation of pregnant women before delivery does not improve significantly the vitamin E status of neonates - low efficiency of the vitamin E placental. Int J Vitam Nutr Res 1998, 68: 293-299.

[71] Mahan DC, Kim YY, Stuart RL. Effect of vitamin sources (RRR- or-rac-alpha-tocopheryl acetate) and levels on sow reproductive performance, serum, tissue and milk alpha-tocopherol contents over a five parity period, and the effects on the progeny. J Anim Sci 2000, 78: 110-119.

[72] Anderson LE, Myer RO, Brendemuhl JH, Macdowell LR. The effect of excessive dietary vitamin A on performance and vitamin $\mathrm{E}$ status in swine varying in dietary vitamin E. J Anim Sci 1995, 73: 1093-1098.

[73] Onibi GE, Scaife JR, Murray I, Fowler V. Supplementary $\alpha$-tocopherol acetate in full fat rapeseed-based diets for pigs: effect on performance, plasma enzymes and meat drip loss. J Sci Food Agric 2000, 80: 1617-1624.

[74] Flachowsky G, lnagbein T, Bohme H, Schneider A, Aulrich K. Effect of false expeller combined with short-term vitamin E supplementation in pigs feeding on the fatty acid pattern, vitamin E concentration and oxidative stability of various tissues. J Anim Phys Anim Nutr 1998, 78: 187-195. 